\title{
微小地震観測による地すべり土塊の三次元形状 と地震応答特性の評価
}

\author{
森 伸一郎 $1 \cdot$ 大竹 秀典 2 \\ 1フェロー 愛媛大学准教授 大学院理工学研究科 生産環境工学専攻 環境建設工学コース \\ (下790-8577 愛媛県松山市文京町3) \\ E-mail: mori@ehime-u.ac.jp \\ 2学生会員 愛媛大学大学院理工学研究科生産環境工学専攻（†790-8577 愛媛県松山市文京町3) \\ E-mail: hidenori.otake.06@cee.ehime-u.ac.jp
}

\begin{abstract}
地す心゙り地の地震時挙動を考えるとき, 地す心゙り土塊の3次元形状と地震応答特性を評価することが重 要である．本研究は,それらの評価を微小地震観測により行うことが有効であることを例示する. 我が国 でも活動度の高い高知県の長者地すべり地で微動観測を行い，昼夜の別なく振動レベルが低く，はじめに 通常の微動計では測定不可能なほどであることを示す。低レベル微動環境は微小地震観測にとっては好都 合である．2日間の微小地震観測で3地震が観測でき，地震応答特性が評価できること，また，卓越振動数 が特定できることを示す。卓越振動数と別途行った表面波探査によって得られた表層の平均せん断速度か ら4分の1波長則で得られた地すべり面深さは，既知のものと15\%程度の誤差で一致した。
\end{abstract}

Key Words : landslide, micro-earthquake, seismic response, earthquake observation, microtremor

\section{1.はじめに}

地す心゙り対策では，すべり土塊の形状や分布状 況を特定することが必要で, まずそのために調査 が行われる。それは，現地踏査によるすべり土塊 の平面形状の把握とボーリング調査によるすべり 面深さの判定からなる. 動きの遅い地すべりの場 合にはボーリング孔を利用して孔内傾斜計による 観測結果により，すべり面を特定することが可能 となる。高密度にこれらを行えばすべり面の形状 を 3 次元的に捉えられる。観測による特定が難し い場合は, すべり面の深度は, 規模, すべり幅・ 長さなどから経験則で推定されることが多い.

すべり面は，粘土鉱物を含んだ堆積岩内や粘土 層で生じるケースが多く, 固さや透水性の異なる 地層境界, 特に流れ盤状に傾斜した地層にすべり 面が形成されることも多く, 地下水浸透で劣化が 進み地す心゙りの誘因となる。一方，対策工事を必 要とする大規模な地すべりのほとんどは, 過去の 活動履歴により，すべり面より上方のすべり土塊 は緩んでいることも多い.

このような地盤構成を地盤振動の観点から見る と，地す心゙り面を境に地盤振動インピーダンスの
コントラストができ，すべり面より上部の土塊の 固有振動が励起されやすい状況となっている可能 性が高い。その場合, 微動測定によりすべり土塊 の固有振動数が特定でき, 別にす心゙り土塊（表 層）のせん断波速度を評価しておけば，それぞれ $10 \%$ 程度の誤差で得られるとすると,すべり土塊の 深さが誤差14\%程度で推定できると考えられる.

この意味を考えてみる。一般の地す心゙り対策の ための調査では, 地すべりブロックに少なくとも 1つ，規模によっては縦横断面上の複数点でボー リング調查と傾斜計による地すべり面の位置特定 が行われる. したがって，十分な数のボーリング でその場合の内挿誤差は小さいと考えられている. 逆に, ボーリング調査の計画の際には, 地すべり 面深さを想定してボーリング長さを決定する必要 がある。この際には，地すべりブロックの長さ

（L）や幅（W）などの幾何学量と深さ（D）の関 係の統計1)，2）利用して推定されることが多い. 上野 ${ }^{1)}$ の文献記載のデータから計算すると, $\mathrm{D} / \mathrm{W} の$

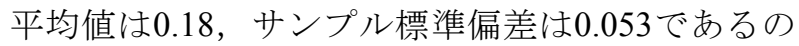
で，変動係数は約 $30 \%$ となり，回帰式を利用した 推定では $68 \%$ の確率で誤差30\%以内に収まると言 える.したがって，ここで提案する方法が30\%よ 


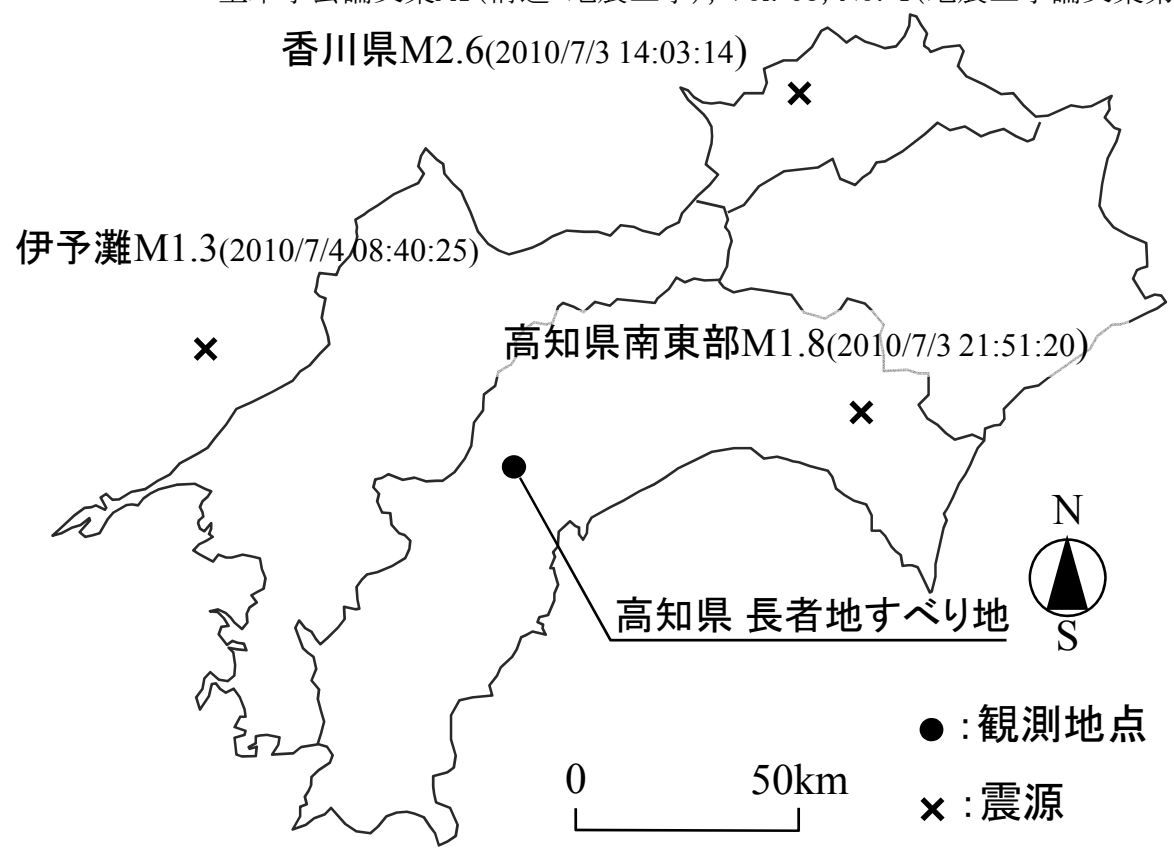

図-1＼cjkstart対象地点と観測された微小地震の震央位置

り小さい誤差で推定できるとすれば，ボーリング 調査に先立つ事前調査として成立するし，また， ボーリング調査による内挿の妥当性を確認するこ とができるものと期待できる.

このように考えると本研究で提案する手法は, す心゙り面の深さの判定やすべり面形状の 3 次元的 な特定のための調查工事に多大な費用と時間がか かっている現状を打破できる可能性がある。これ らが短時間で経済的にできるのであれば，ボーリ ングの特定精度に比べて低くても十分に有用であ る。特に，時間的に効果的な手法であれば，実務 的にも大変有用な手法となりうる。このような観 点から, 微動調查法の適用性を表面波探查と併せ るなどして開発している3),4).

一方，地すべり地は山間地に位置するため，特 に1 Hz以上の振動数領域での微動源として寄与の 大きい交通振動，機械振動などの人間活動は都市 域に比較して格段に低い。そのため微動探查 ${ }^{5}$ に とっては超低レベルの微動環境 ${ }^{3}$ を原因として探 査ができないことが懸念される。したがって, 微 動調查を地す心゙り地に適用するためには, 高感度 地震計である微動計の電源ノイズ, 機器ノイズな ど電気ノイズを上回る微動信号が必要となる. SN 比の問題もさることながら, 信号そのものが検出 できるかどうかに適否が左右される゙.

その点, 逆に微動レベルが低いということは, 地震観測の立場から見れば微動はノイズとなるの で，ノイズレベルの高い都市域に比べて極めて低 い微動環境は微小地震観測には好都合である。特 に, 最近では気象庁や防災科学技術研究所により 毎日の発生地震の諸元決定が一元化され，翌日に はインターネットを通して入手することができ, 独自の観測記録での微小地震 $(\mathrm{M}=1 \sim 3)$ はもちろ
几極微小地震（ $\mathrm{M}<1)$ の特定が容易になっている。 水平成層仮定の表面波の理論に基づく逆解析に立 脚した微動調查の適用が多い都市域に比べて, 微 小地震観測は山間地・過疎域や地方中小都市の有 効な地盤調查法となる可能性を秘めている77.

さらに, 今後に懸念される東南海地震・南海地 震などの広域に影響を与える大規模地震を考える と, 地す心゙りの地震時挙動やそれによる活性化な どが懸念される. 地すべり地の地震時挙動を考え るとき, 地すべり土塊の3次元形状と地震応答特 性を評価することが重要である.

本論文は，そのような観点から微小地震観測に よる地すべり地の地震応答特性を評価する ${ }^{8}$ こと により, 地すべり地で要求される項目の調査がで きる可能性を例示するものである.

\section{2. 長者地すべり地における微小地震観測}

\section{（1）観測対象とする長者地すべり}

微小地震観測をこれまで実施した地すべり地は, 愛媛県大洲市佐賀畑, 高知県大野市八墒, 高知県 長者の3地区である，観測の際には，併せて測線 微動測定も実施している。ここでは, 四国でも地 すべり活動が大規模, 大変位で長期間にわたり対 策が継続して行われている長者地すべり地を対象 に報告する。

図-1に対象地点である長者地すべり地（地震観 測地点）の位置と後述の観測された微小地震の震 央位置を示す. 長者地すべり地は, 高知市の西北 西約 $40 \mathrm{~km}$ に位置し、一級河川仁淀川の支川であ る長者川に沿う仁淀村長者にある。ここは大規模 な蛇紋岩地すべり地として全国的に知られており， 
延歴 11 年（792 年）の大崩壊，寛政4 年（1792 年)，文政5 年（1822 年）に大洪水による地すべ り災害が仁淀村史 ${ }^{9}$ などで記述されている。近年 では，昭和33 年に建設省所管の地すべり防止区域 に指定され，昭和 28 年度から「地すべり対策事 業」により対策工も行われているが，現在でも地 すべり活動は依然として継続している.

また，図-2に長者地すべり地の主要な地すべり 区域を示す。地す心゙り土塊の規模は, 幅約 $200 \mathrm{~m}$, 長さ約 $900 \mathrm{~m}$ ，平均斜面勾配 15 度であり，北方向

（長者川方向）に移動している. 移動地すべり土 塊は5個の直列するブロックから構成されており， 最下部のブロックとその直上のブロックとの境界 に町道が走っている。この町道に沿い，2ブロッ クを横断するように18個の測点を配置して単点微 動観測を行うとともに，5点での同時微小地震観 測を行った。単点微動観測は，この測線以外に13 地点でも行った.

\section{(2) 微動観測と微小地震観測の方法}

観測に用いたのは，動電型の速度計で， $4.5 \mathrm{~Hz}$ の固有振動数を有する振動子をコンデンサーレギ ユレーション方式（CR方式）で，0.5〜20 Hzでほ ぼ平坦な周波数特性を有する速度計CR4.5-2S（物 探サービス製）と計測器GEODAS-10-24USB（物 探サービス製）である。長周期側は2秒まで測定 することができる。

P1からP18の測点の内，測点P1とP18はブロック の東外側に, 測点P16とP17はブロックの西外側に, 残りはブロック内に配置した。 微小地震観測を行 ったのは, 中心線より東側で, P18, P2, P3, P7, P10の5点であり，P18はブロック外側，P2は側方 境界線上，P3 は上下境界線上，P7と P10は歴史的 に大きく移動している最下部ブロック中央である. センサーの設置は，P1，P3〜P17についてはアス ファルト舗装道路面上, $\mathrm{P} 2$ につては車庫床コン クリート面上，P18については斜面上の石階段上 である。図-3に町道に沿うP2，P3，P7の地震計を 配置した状況の写真を示す。P2からP3にかけて4 $\mathrm{m}$ 程度低くなっている様子がわかる。P18では不動 側にあるのに対して，P7，P10などの移動土塊中 央部では，下方基盤に対して明瞭な構造境界を持 ち，波動インピーダンスも異なっていると思われ る。

微動観測では， $10 \mathrm{~Hz}$ 前後の卓越振動を想定して, サンプリング周波数 $200 \mathrm{~Hz}$ で行い，1 1 所5分間測 定を2回行った。測定は，2010年7月2日12:30〜 19:20に実施した。解析では，10.24秒を1セグメン トとし，オーバーラップなしで8セグメントを平 均化し, バンド幅 $0.2,0.4,0.7,1.0,2.0 \mathrm{~Hz}$ の Parzenウィンドウで平滑化し，それぞれ1，2，4， 10，20 Hz付近のスペクトルピークを判読するのに

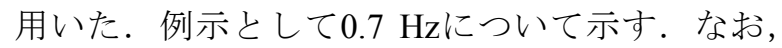
ウィンドウ処理は微小地震動についても, サンプ リング周波数は違うが, 同様のバンド幅のParzen

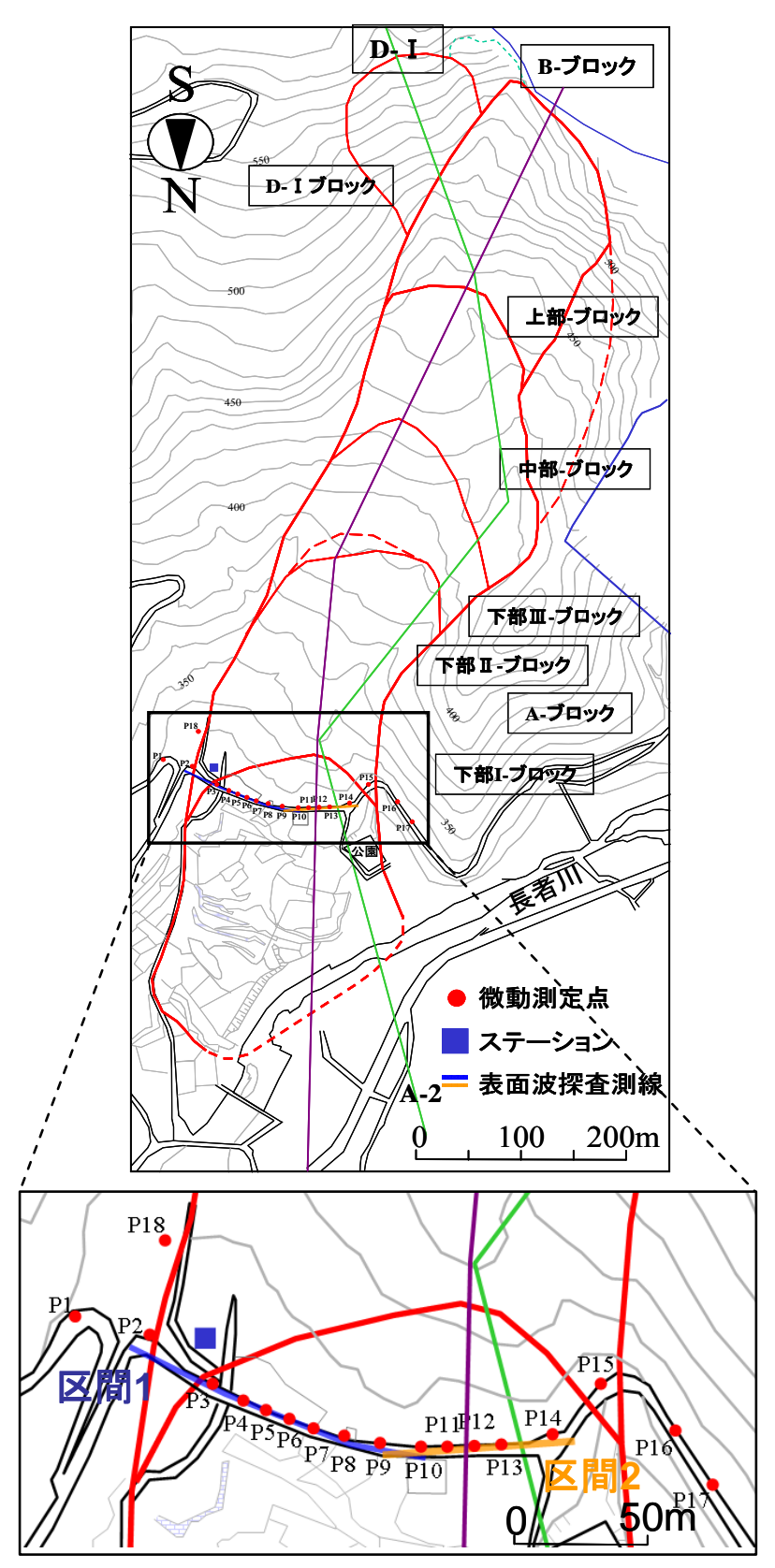

図-2 長者地すべり地の主要な地すべり区域

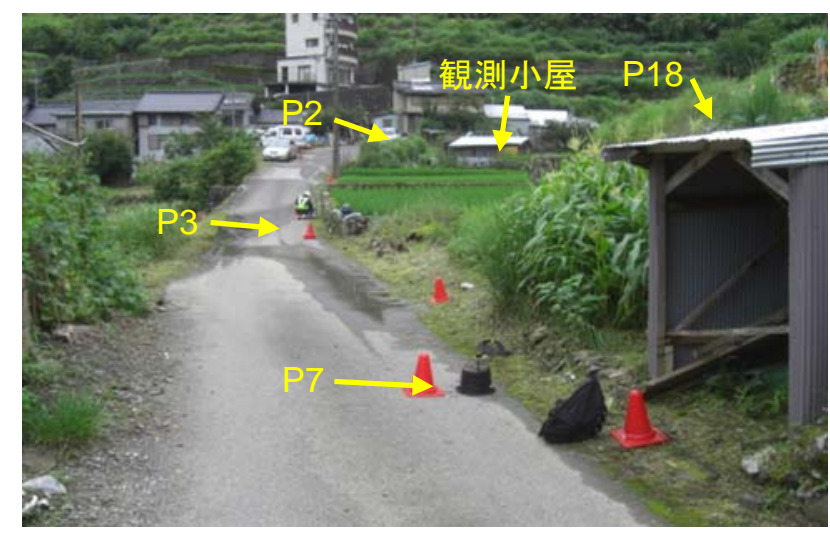

図-3 測線付近の地形と地震計配置の状況 
ウィンドウを用いた

微小地震観測は，2010年7月2日（金）19:30から 7月4日（日）14:20までの43時間行った。データ数 削減のためサンプリング周波数を $100 \mathrm{~Hz}$ と， 30 分間の記録を1セットとする連続観測を行い, 86

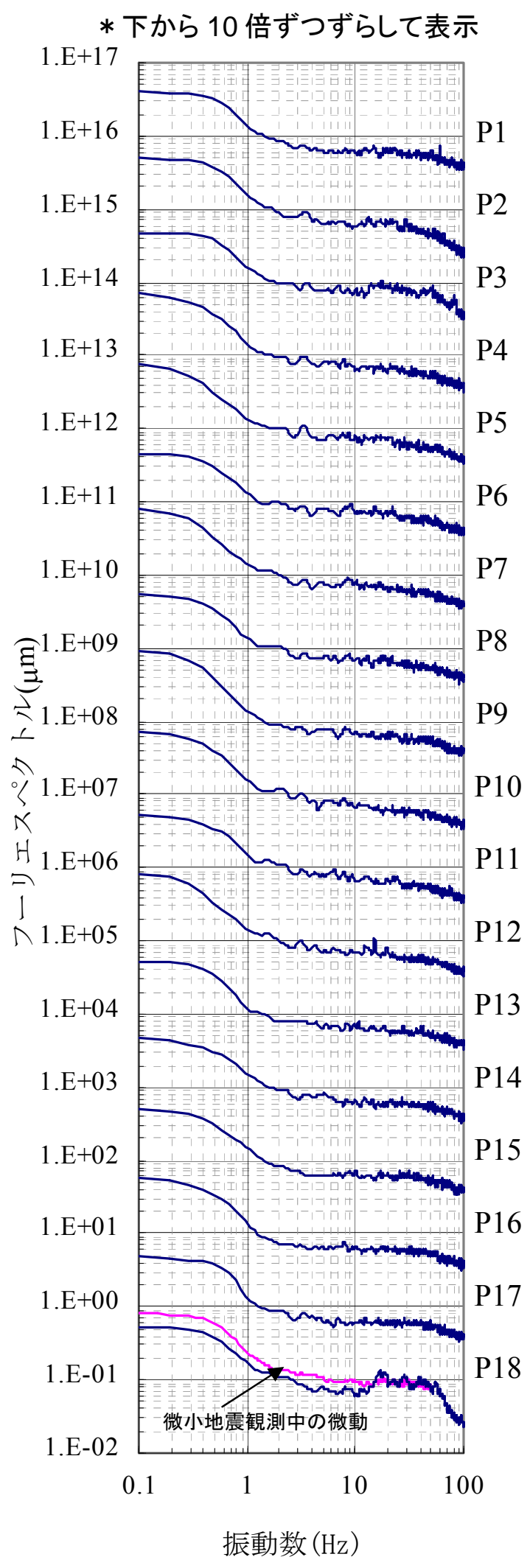

図-4 全測点における微動の NS 成分速度フーリ エスペクトル
セットのデータを得た。

(3) 微動観測の結果

図-4に全測点における微動のNS成分フーリエス ペクトルを示す. 平均化とバンド幅 $0.7 \mathrm{~Hz}$ のParzen ウィンドウ処理を行ったものである. 全地点とも ほとんど同じである。P18については，12Hz以上 の高振動数成分に他の地点との違いがある. 単点 微動観測時に古い石造の階段に置いたが，浮いて いた可能性がある。地震観測では $40 \mathrm{~cm}$ 程度離れた 別の大きな石の上にセンサーを置くことで，高振 動成分の無いことを確認した。図中にはその際の 微動のスペクトルを重ねて示す.

そこで速度計の電気ノイズによる記録を調べる ため，振動子が動かないようにして測定した結果 を電気ノイズとして記録した。図-5にブロック中 央で最も土塊厚さが厚い（すなわち，最もゆれや すい）と期待されるP10とブロック外側で傾斜面 の良好な切り土地盤上の道路上の地点である $\mathrm{P} 1$ の 2地点でのNS成分のスペクトルと電気ノイズを示 す.P1では微動と電気ノイズはほとんど変わらな い. 一方, P10では8 Hz付近で微動がやや電気ノイ ズに比して卓越するようにも見えるが, やはり有 意な違いは無いと言える。

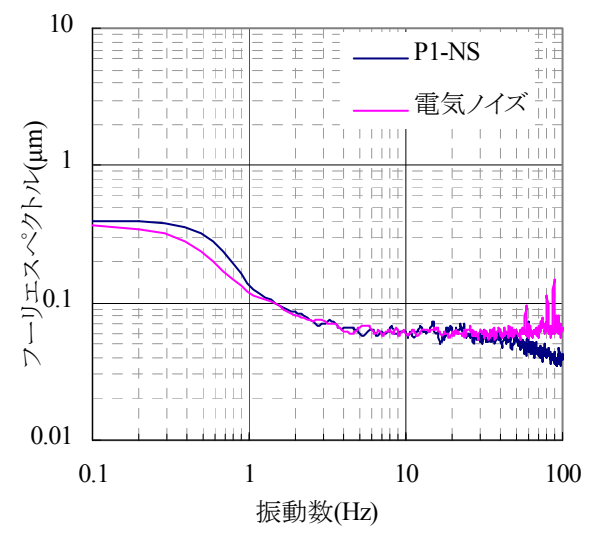

(a) P1の NS 成分

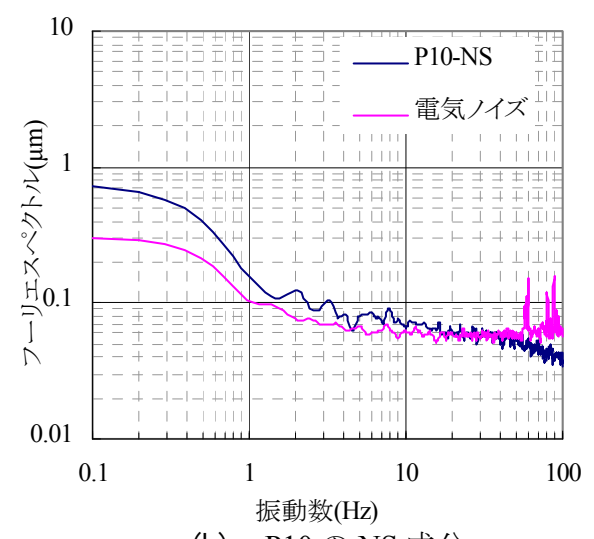

(b) P10 の NS 成分

図-5 P1 と P10の NS 成分の微動スペクト ルと電気ノイズ 


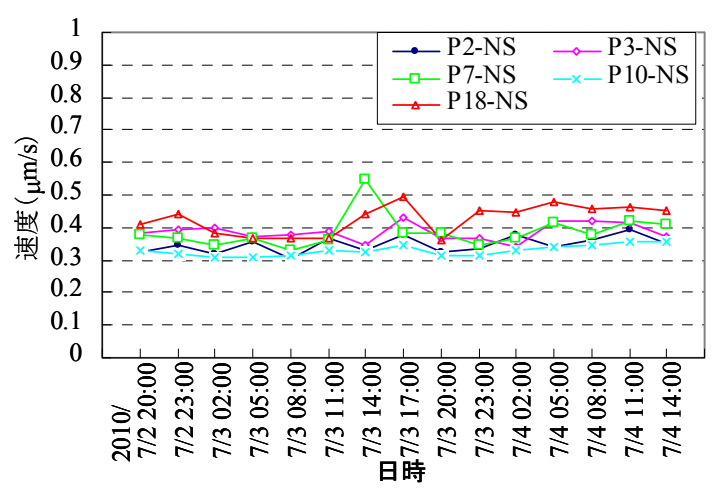

(a) NS 成分

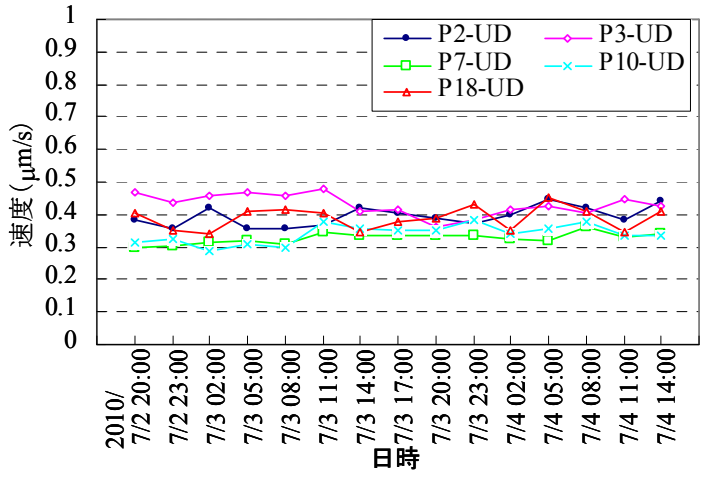

(b) UD 成分

図-6 微動の NS 成分と UD 成分の 80 パーセント振幅の時間変動（45 時間）

このような特徵について普遍的なのかどうか調 ベるために，観測した43 時間の記録より，3 時間 間隔で20.48 秒間を1セグメントとした速度波形振 幅データを対象にして算出した平均值, 標準偏差, 80パーセンタイル值の時間変動を調べた. 図-6に

(a) NS成分と (b) UD成分の 80 パーセント振幅の 45 時間の時間変動を示す. 概ね2 2 日分の時間変動で あるが, 日周期の変動は明瞭でなく, 微動におけ る人間活動の影響はほとんど見られないことがわ かる，したがって，地すべり地特有の傾向である と言える。

すなわち，当該地すべり地では，微動探査は有 効に用いることができないと判断できる。一方, 微動レベルが安定して低いというのは，微小地震 観測にとっては好条件であると言える。都会では 考えられない中山間地の特徴である。

（4）微小地震観測の結果

\section{a） 観測できる地震の範囲}

地震動の振幅が距離減衰式でモデル化されるよ うに，震源距離Xとマグニチュード $\mathrm{M}$ の関係より， 微小地震が地震動として観測される可能性の目安 がわかる. Hi-netの一元化処理震源リスト ${ }^{10)}$ から観 測中に発生した全ての地震の緒元を整理しこの関 係を求める.

図-7に43時間でHi-netで観測された地震の震央 距離とMの関係を示す. 観測中に744個の地震が観 測されている. P波速度を5〜7 km, S波速度を3〜 $5 \mathrm{~km}$ とすると, 地震波の伝播速度を 3 ～ $7 \mathrm{~km}$ とし て，各地震の発震時刻に伝播時間を加えることで 地震波到着時間帯が算定できる。その時間帯で地 震波として認識できる位相がないか調べる。図中 には発震時刻と我々の観測記録波形より微小地震 と認識できた3つの地震を明示した。これらの3地 震以外の地震では地震波形を認識できなかった。

したがって，適当な距離減衰式を仮定して一定の

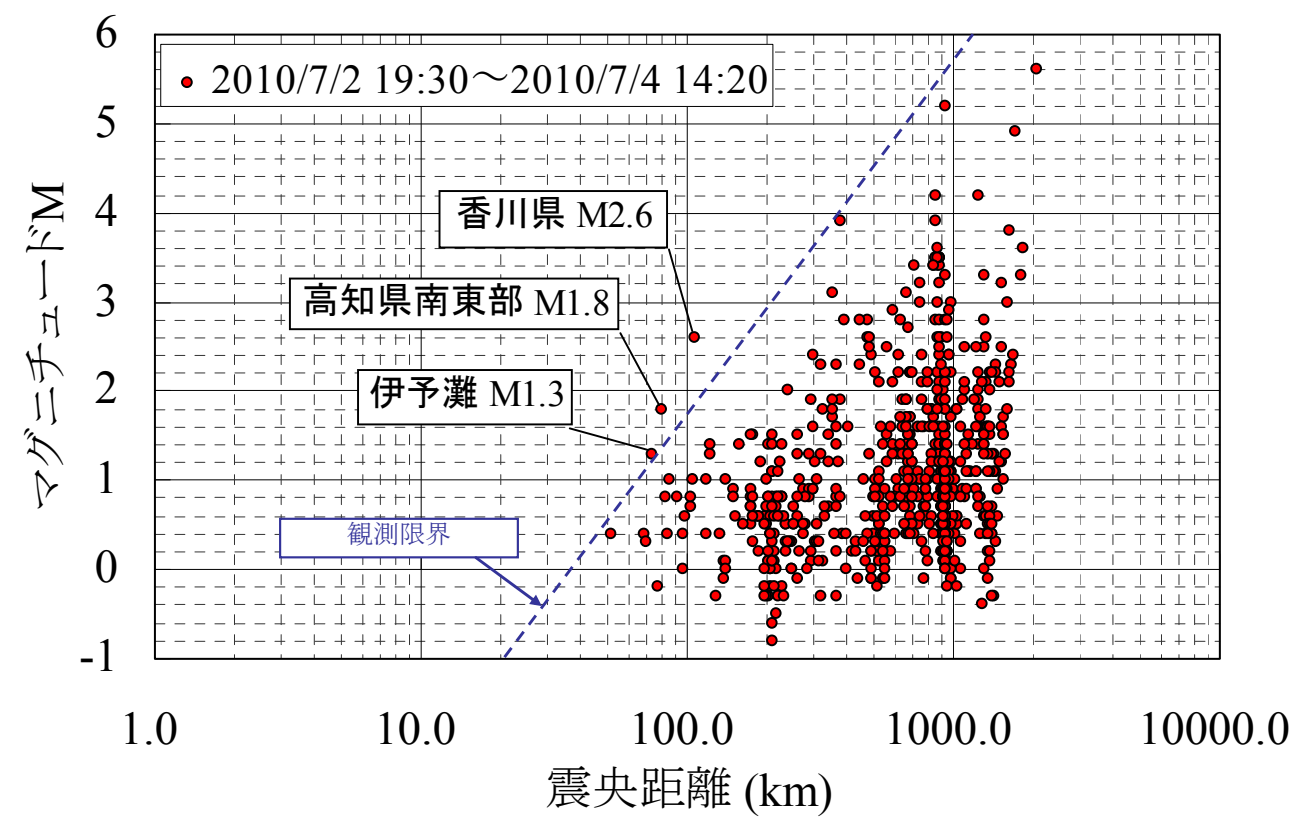

図-7 43 時間で Hi-net で観測された地震の震央距離と $\mathrm{M}$ の関係 （長者地すべり地で観測された 3 地震を示す。） 
表-1＼cjkstart観測された $3 つ の$ 微小地震の諸元

\begin{tabular}{|c|c|c|c|c|c|c|c|c|c|}
\hline $\begin{array}{l}\text { 地震 } \\
\text { 番号 }\end{array}$ & \multicolumn{2}{|c|}{ 発震日時 } & 震源地域名 & 緯度(度) & 経度(度) & $\begin{array}{l}\text { 深さ } \\
(\mathrm{km})\end{array}$ & Mjma & $\begin{array}{c}\text { 震央距離 } \\
(\mathrm{km})\end{array}$ & $\begin{array}{c}\text { 方位角 } \\
\text { (度) }\end{array}$ \\
\hline EQ 1 & \multicolumn{2}{|c|}{ 2010/7/3 14:03:14 } & 香川県 & 34.267 & 133.836 & 16.2 & 2.6 & 107 & 37 \\
\hline EQ 2 & \multicolumn{2}{|c|}{ 2010/7/3 21:51:20 } & 高知県南東部 & 33.614 & 133.98 & 17 & 1.8 & 80 & 81 \\
\hline EQ 3 & \multicolumn{2}{|c|}{ 2010/7/4 08:40:25 } & 伊予灘 & 33.745 & 132.386 & 47 & 1.3 & 74 & 292 \\
\hline \multicolumn{2}{|c|}{ 測定場所 } & \multicolumn{2}{|c|}{ 緯度(度) } & & & & & & \\
\hline \multicolumn{2}{|c|}{ 長者地すべり地 } & 33.498 & 133.131 & & & & & & \\
\hline
\end{tabular}

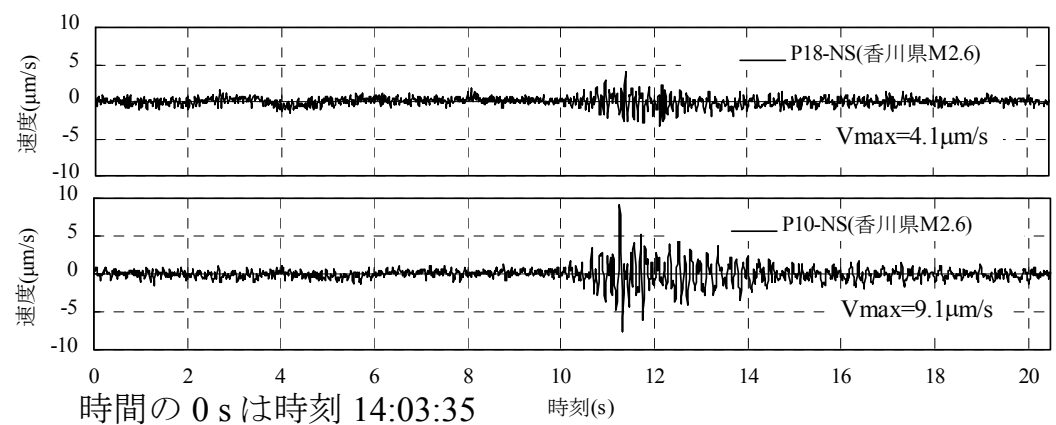

(a) P18,P10における地震動（香川県 M2.6，EQ1）の NS 成分時刻歴

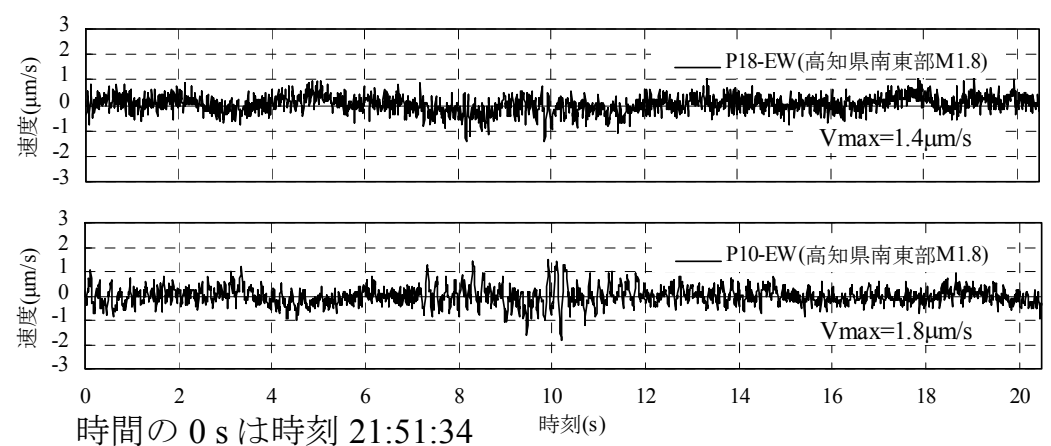

(b) P18,P10における地震動（高知県南東部 M1.8, EQ2）の EW 成分時刻歴

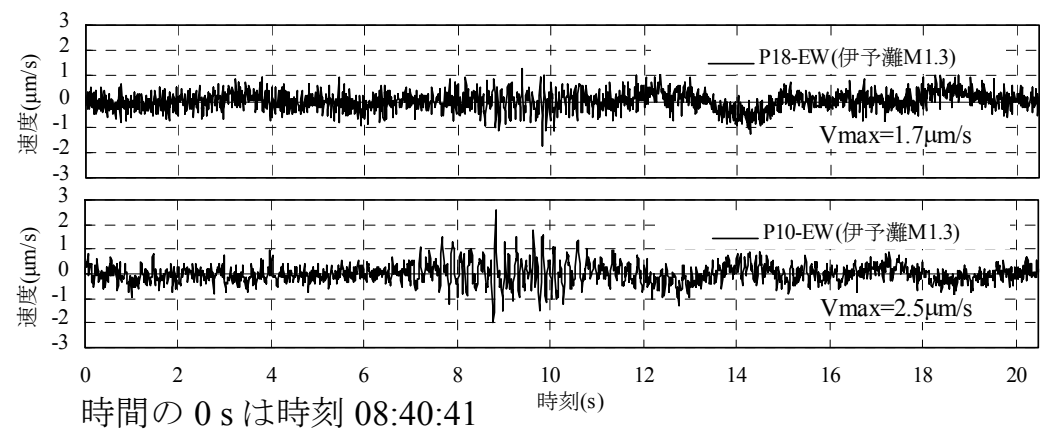

(c) P18,P10における地震動（伊予灘 M1.3，EQ3）の NS 成分時刻歴

図-8 P18,P10 における 3 つの地震動の水平動時刻歴

速度振幅を示す右上がりの直線で観測限界を設定 することができるであろう。震央距離 $\Delta=50 \mathrm{~km}$ $\mathrm{M}=0.4$ の地震と $\Delta=380 \mathrm{~km}$ で $\mathrm{M}=3.9$ の地震が観測さ れているかどうかが問題であったが，電気ノイズ
に埋もれており，図に示した観測限界を確認でき た。

b）観測できた地震動から抽出できる情報

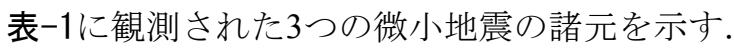




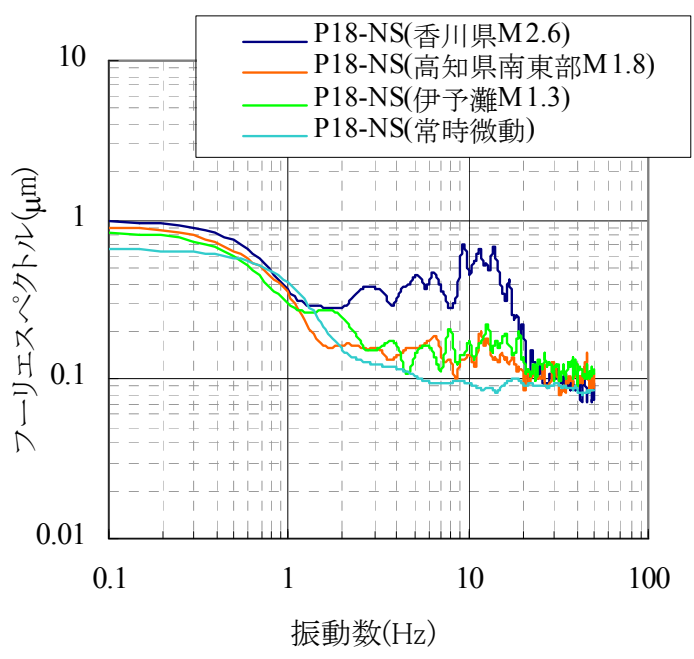

(a) P18 地点

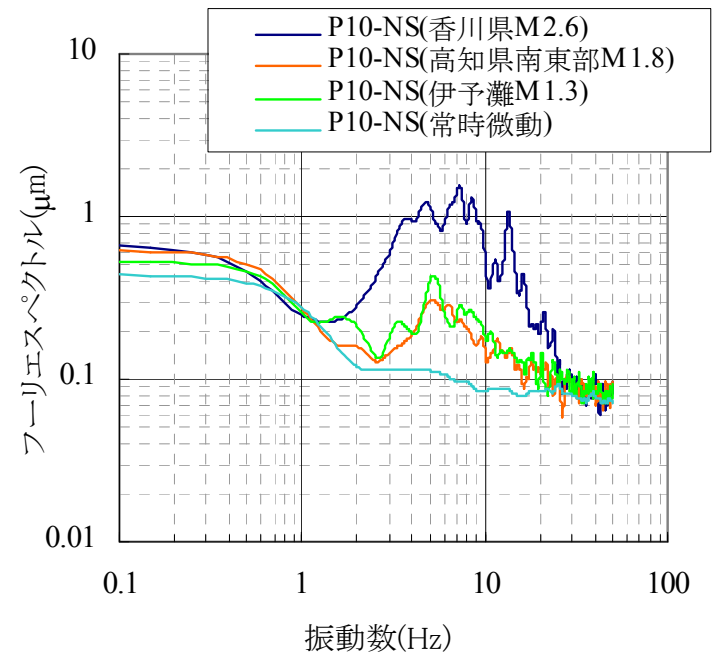

(b) P10 地点

図-9＼cjkstart微小地震動と微動の NS 成分のフーリエスペクトル

また，震央は図-1に示したように観測点から見て 震央方位角が37度，81度，292度となるようにさ まざまな方向に位置している。5つの観測点の中

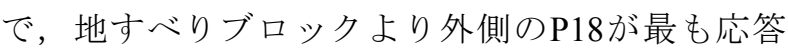
が低く，地すべりブロック中央のP10が最も応答 が大きくなることが予想される。 そこで，これら 2点のNS成分について見てみる.

図-8に上記2地点における3つの地震動の水平動 時刻歴（振幅が大きい方向成分）を示す。香川県 M2.6の地震（EQ1）が最も応答振幅が大きくなっ ており，2地点ともに明瞭な地震波形が認められ

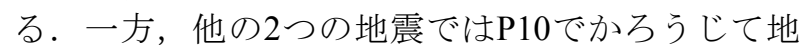
震波形が認められるが，P18では認められない.

そこで，図-9に微小地震動と微動のNS成分のフ ーリエスペクトルを示す。この際の微動のスペク トルは，微小地震観測中に観測された微動を解析 したものであり，単点微動観測の解析とは異なり, 観測条件 ・解析条件は微小地震動のそれに合わせ ている.

良くゆれると予想されたP10では，いずれの地 震でも微動レベル（電源ノイズ相当）を有意に上 回っており，EQ1では1.8 HzでSN比2以上を確保し ているし，EQ2とEQ3では4.5 Hz以上でSN比2以上 を確保している.

あまりゆれないと予想されたP18でも，EQ1では $2.0 \mathrm{~Hz}$ でSN比2以上を確保しているが，EQ2とEQ3 では11 Hz付近を除き, 全域でSN比2を確保できな い. 6〜20 HzではSN比がやや大きく，かろうじて 振動がノイズより大きい.

そこで，地震応答特性として評価できるのかど うかを, 最も安定した地点に対する周波数応答特 性で評価することを考え，その様子を検討する。

図-10にP18に対するP10の周波数応答特性 $(\mathrm{H} / \mathrm{H}$ 比）を示す. EQ1では4〜 $5 \mathrm{~Hz}$ と〜 9 Hzの2ケ所で
3〜4倍の増幅を示すピークがあるが， EQ2 と EQ3 でも $5 \mathrm{~Hz}$ 付近と 7 9 Hzの2箇所で2倍の増幅を示す ピークがあり, 地震方位角が異なり, マグニチュ 一ドが異なってはいるが, 卓越振動数としては安 定して現れていると言える。Mが小さい地震で増 幅が小さいのは，基準としているP18では電気ノ イズに埋もれている振動数成分があり, その分, 増幅を小さく見積もることになる。したがって， 振動レベルが低い場合には増幅を議論することは できないが，卓越振動数を推定することには利用 できる可能性がある. 卓越振動数の推定ができ, かつ表層地盤のせん断波速度を他の方法（表面波 探査など）で知ることができれば，表層厚さを推 定することができることにつながり，地すべり土 塊の表層厚推定のための有効な概略探査法として 成り立つと考えられる.

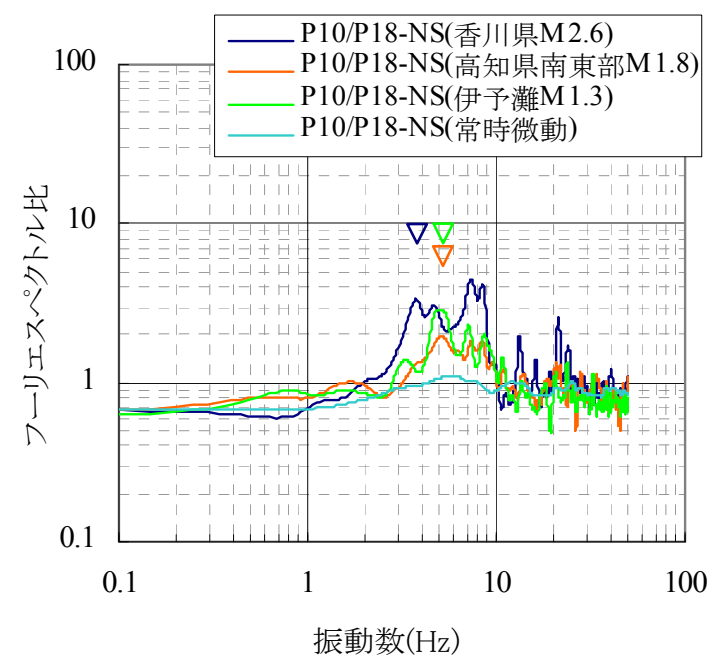

図-10 P18 に対する P10 の周波数応答特性 $(\mathrm{H} / \mathrm{H}$ 比) 


\section{3．長者地すべりの地震応答特性}

\section{（1）P18を基準にした水平動スペクトル比}

前章末節で検討したように，微小地震観測によ る地震動のスペクトルやスペクトル比は，地震応 答特性を評価するのに適していることがわかった。 振幅特性を議論するにはある程度のSN比が必要で あろうが, 卓越振動数の評価にはより低振幅の地 震動でも有効であることがわかった。

そこで，本章では，地すべりブロック境界外側 に位置するP18を基準にした場合の各地点の水平 動の地震応答特性を論じる。

図-11にP2，P3，P7の水平動スペクトルとP18を 基準にした水平動スペクトル比（H/H比）を示す. これは相対的な増幅スペクトル特性を表す.

P18 と同じく，すべりブロックの東境界の外側 にあるP2については，香川県M2.6の地震では1.5〜 $16 \mathrm{~Hz}$ でSN比2以上を確保しているが，高知県M1.8 と伊予灘M1.3ではSN比2を確保できていない。香 川県M2.6の地震ではH/H比は7〜9 Hzで1.5倍程度 と見ることもできるが 2 〜 $16 \mathrm{~Hz}$ でH/Hは，おおよ そ1である。したがって，P2はP18と同様に，地す ベりブロックに比して硬い地山であり，相対的に 増幅特性に違いがないと言える。他の2つの地震 も同様の形状である。電気ノイズレベルと等しい 微動も同様の形状を呈しており，形状の類似性の みから無批判に硬い地山であるとの解釈をするこ とが危険であることがわかる。

すべりブロックの東の内側にあるP3については, 距離的にP2に近いといえども，スペクトルは明瞭 に異なる振動特性を呈している。 H/Hスペクトル 比を見れば，微動は平坦な様子であり，電気ノイ ズのスペクトル比を見ているに他ならない。P3に ついては小さい2地震においても4〜10 HzでSN比 が 2 以上であり，H/H比で4〜 $10 \mathrm{~Hz}$ の領域で見られ る7〜 $8 \mathrm{~Hz}$ に明瞭な卓越のあるピークが3地震共通 して認められる。増幅が香川県M2.6の地震に比べ て他の地震で小さいのは, SN比の低さに起因して いる.

\section{（2）P18を基準にした水平動最大値}

前節で検討した結果, 卓越振動数周辺以外では $\mathrm{SN}$ 比が低くスペクトル増幅特性も評価できないこ とがわかった。したがって，スペクトル特性が反 映される時刻歴振幅特性にも低SN比の影響が現れ るはずである。しかしながら，最大值の応答特性 もまた重要であるので, どの程度信頼できるのか を検討しておくことは重要である.

図-12に最大速度の空間分布を示す. P18が最も 小さく，それを基準にすると， $\mathrm{SN}$ 比の最も良い香 川県M2.6地震では，P7，P10で増幅が大きく， NS 成分（斜面傾斜方向）で2倍程度，EW成分（斜面 走行方向）でも2倍程度，UD成分でも2倍程度とな る. 他の2地震では水平動において傾向は捉える

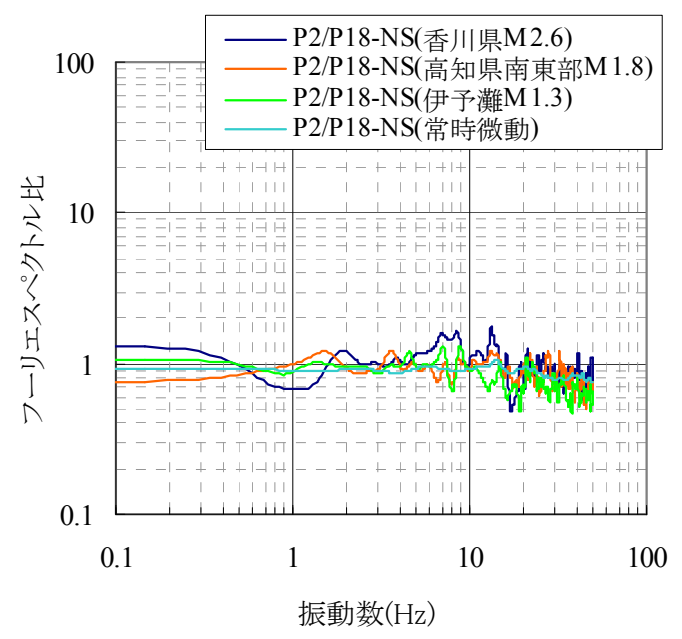

（a） P2 の水平動スペクトル比(H/H 比)

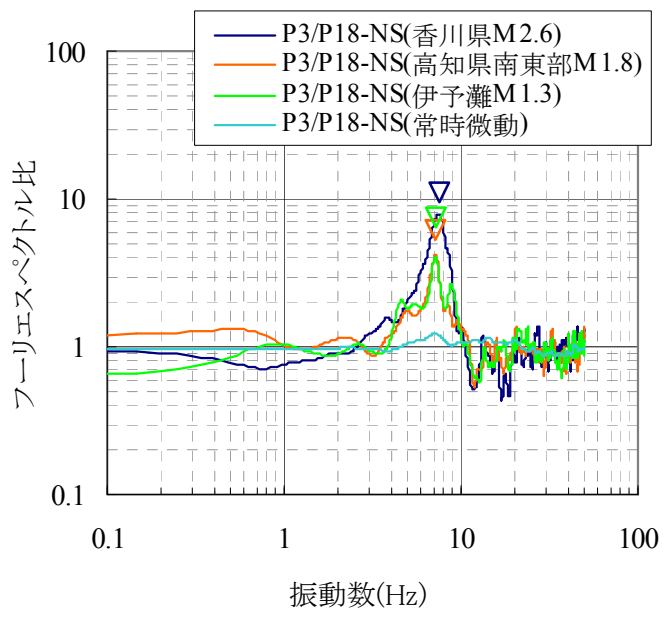

(b) P3 の水平動スペクトル比 $(\mathrm{H} / \mathrm{H}$ 比)

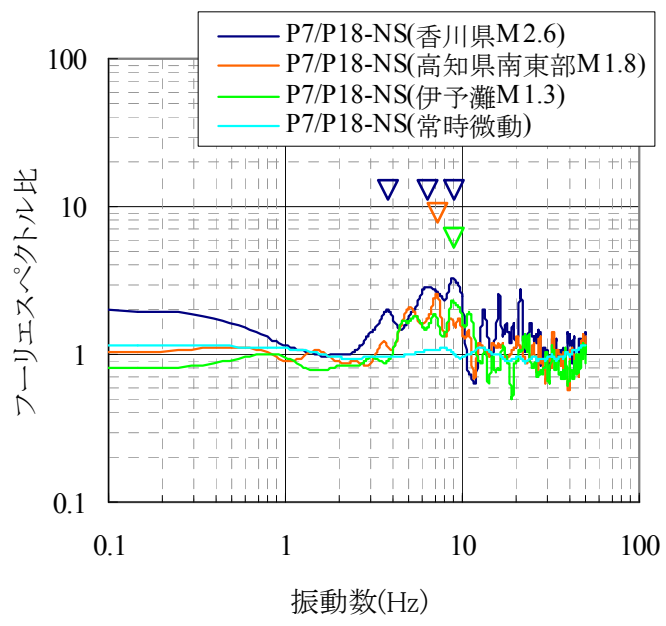

（c） P7 の水平動スペクトル比 $(\mathrm{H} / \mathrm{H}$ 比)

図-11 P2,P3,P7 の水平動スペクトルと P18 を基 盤にした水平動スペクトル比 $(\mathrm{H} / \mathrm{H}$ 比 $)$ 


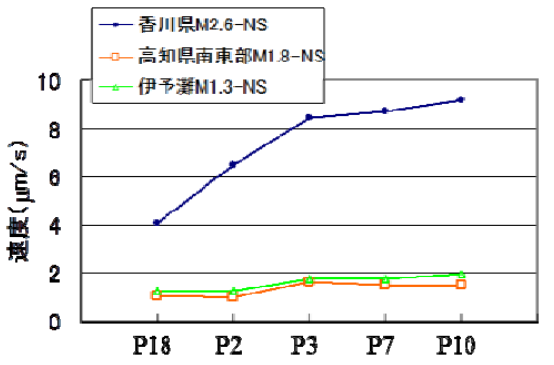

(a) NS 成分

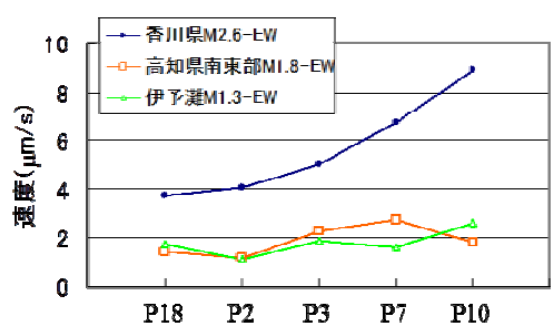

(b) EW 成分

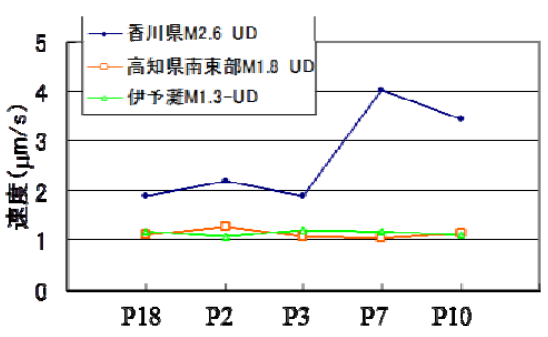

(c) UD 成分

図-12 地震動最大速度の空間分布

ことができるが，増幅率は小さく評価することと なる。これは基準となる点の地震動が小さいため である。また，UD成分では，他の地震では概ね増 幅率は 1 とり, 電気ノイズに埋もれて, まとも な評価はできないことを表している.

\section{4. 長者地すべり地の地すべり面深さの推定}

\section{(1) 微小地震観測点での卓越振動数}

図-11に示したフーリエスペクトル比から読み取 った各地点での卓越振動数を表-2に一覧にして示 した。表には，SN比が2以上となる有効下限振動 数 $f_{\text {low }}$, それより高振動数側にある卓越振動数 $f_{\mathrm{p} 1}$, $f_{\mathrm{p} 2}, f_{\mathrm{p} 3}$ を読み取った。ここで下付け文字の数字に 意味はない。読み取りは，バンド幅1.0 HzのParzen ウィンドウを施したスペクトル比に基づいた.

P3では，3つのどの地震でも7.1〜 7.3 Hzに増幅率 が4〜7.5にもなる単一の鮮明なピークを持つもの となった。比較的均質な表層を持ち，基盤との波 動インピーダンス比の小さいコントラストのある 地盤構造が期待される。

P7では，9 Hzと6〜 7 Hzに局所的ピークが認めら れるが，いずれの地震でも3.7〜 $10 \mathrm{~Hz}$ にかけて2〜 3の増幅率を有するゆるやかな増幅状況である.

SN比の良いEQ1では3.7Hzに増幅率2以上の有意な ピークが見られる。複数の材質層からなる表層を 持ち，3.7Hzの増幅に対応する基盤との間にはそれ ほど強いコントラストがないのかもしれない.

P10では，増幅する振動数範囲は3〜 $10 \mathrm{~Hz}$ であり， 7.3〜8.6 Hzと3.7〜 5.1 Hzの2つにピークが認められ る.
P2はP18との比では相対的増幅が認められず, 双方とも地すべりブロック下方の地盤と同等の堅 固な地盤であると推察される。ここでは, SN比の 良いEQ1の卓越振動数を以て, 各地点の地すべり 面深さを推定する卓越振動数を特定する.

\section{（2）表面波探査と表層平均せん断波速度の設定}

表層平均せん断波速度の設定には, ボーリング 孔を用いたPS検層, 弾性波探査, 表面波探査, 標 準貫入試験結果と経験式による推定など, さまざ ま考えられる。ここでは, 著者らの利用可能性と いう観点から，表面波探査に基づいて設定するこ ととした.

測線に沿って表面波探査を行い表層のせん断波 速度分布を明らかにした。探査には, 多チャンネ ル地震探査装置McSEIS-SXWを用いるとともに, センサーは固有振動数 $4.5 \mathrm{~Hz}$ の上下動速度型のジ オフォンを使用した. ジオフォン 24 個を $2 \mathrm{~m}$ 間隔 で配置し，ランドストリーマーケーブルを使用し， 46 m長さに配置されたジオフォン群を移動させて 連続的に探査した。表面波を励起させる打撃起振 はかけやによった。探査測線をとる道路が曲がっ ていたので, P2〜P10間（区間1, 距離 $112 \mathrm{~m}$ ） と P9〜P14間（区間2，距離62 m) の2つの直線分に 分けて実施した。この間では測線を設定した道路 は緩やかに2度逆方向に蛇行している。そのため， 部分的に堆積土層厚さが厚い方または薄い方に偏 るものと推察される。また, P2側は地理的制約に よりハンマー打点を遠くに置けなかった.

ジオフォン配置長さが46 mであるので, その $1 / 2$

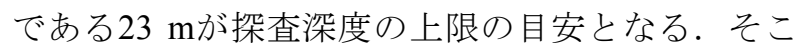
で，20 mまでを探査深度として分析した。ここで

表-2 各地点での卓越振動数一覧（単位は $\mathrm{Hz}, f_{\mathrm{p} 1} \sim f_{\mathrm{p} 3}$ が卓越振動数）

\begin{tabular}{|c|c|c|c|c|c|c|c|c|c|c|c|c|c|}
\hline \multirow{2}{*}{$\begin{array}{l}\text { 地すべりブロック } \\
\text { との関係 }\end{array}$} & \multirow{2}{*}{ 地点 } & \multicolumn{4}{|c|}{ EQ1 } & \multicolumn{4}{|c|}{ EQ2 } & \multicolumn{4}{|c|}{ EQ3 } \\
\hline & & $f_{\text {low }}$ & $f_{p 1}$ & $f_{p 2}$ & $f_{p 3}$ & $f_{\text {low }}$ & $f_{p 1}$ & $\mathrm{f}_{\mathrm{p} 2}$ & $f_{p 3}$ & $f_{\text {low }}$ & $f_{p 1}$ & $f_{p 2}$ & $f_{p 3}$ \\
\hline ブロック外 & P18 & 2.0 & NA & NA & NA & 11.0 & NA & NA & NA & 11.0 & NA & NA & NA \\
\hline ブロック境界 & P2 & 1.8 & - & - & - & 11.0 & - & - & - & 11.0 & - & - & - \\
\hline ブロック内 & $\mathrm{P} 3$ & 2.0 & - & 7.5 & - & 4.8 & - & 7.1 & & 4.8 & - & 7.1 & 8.9 \\
\hline ブロック内 & P7 & 1.9 & 3.7 & 6.3 & 9.0 & 4.5 & - & 7.1 & - & 4.9 & - & - & 9.0 \\
\hline ブロック内 & P10 & 1.8 & 3.7 & 7.3 & 8.5 & 4.5 & 5.1 & 7.1 & 8.7 & 4.5 & 5.1 & 7.3 & 8.6 \\
\hline
\end{tabular}




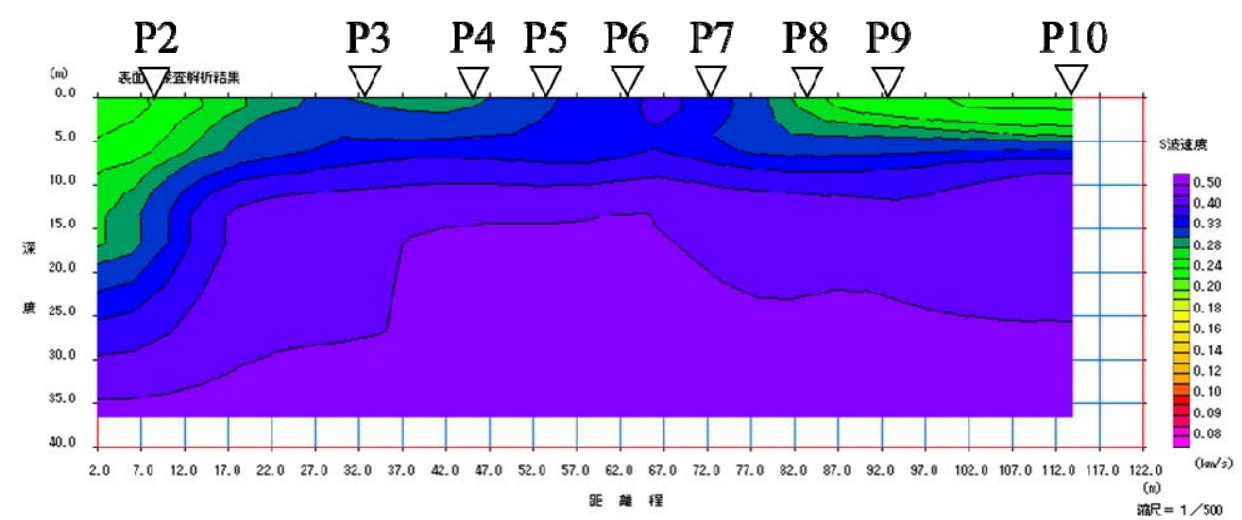

(a) 区間 1

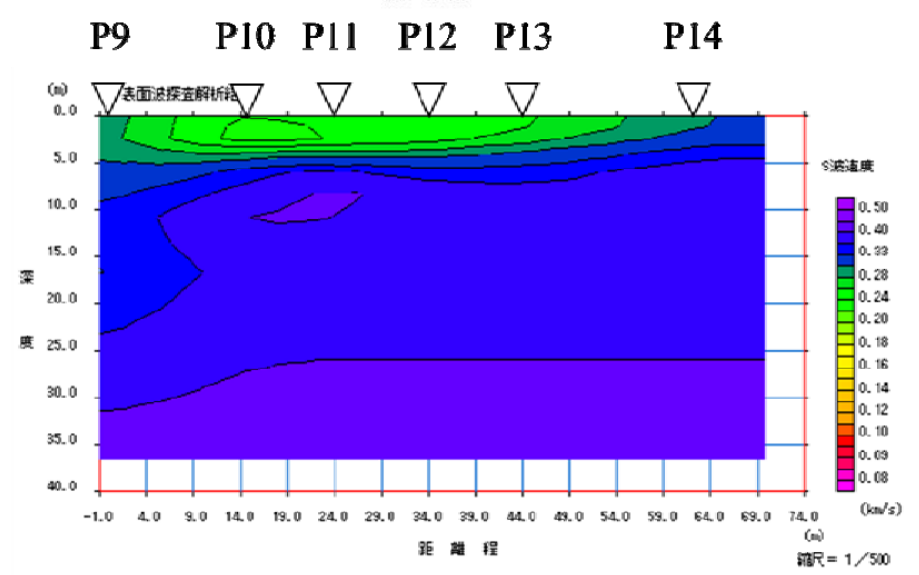

(b) 区間 2

図-13＼cjkstart測線に沿うせん断波速度（Vs）の２次元分布（(a) 区間 1 と（b) 区間 2)

表-3 測線に沿うせん断波速度（Vs）の一覧（区間 1）

\begin{tabular}{|c|c|c|c|c|c|c|c|c|c|c|c|c|c|c|c|c|c|c|c|c|c|c|c|c|c|c|c|c|}
\hline \multirow{2}{*}{$\begin{array}{c}\text { 下端深度 } \\
(\mathrm{m})\end{array}$} & \multicolumn{28}{|c|}{ एक } \\
\hline & $\bar{n}$ & & $\sqrt{\mathrm{m} m}$ & & $3 \mathrm{~m}$ & $2 z m$ & $26 \mathrm{~m}$ & $30 \mathrm{~m}$ & 341 & & & & & $54 \mathrm{~m}$ & $58 \mathrm{~m}$ & $62 \pi$ & & & & & & & & & & & & \\
\hline 0 & & & & & & & & & & & & & & & & & & & & & & & & & & & & \\
\hline III & 32 & 39 & 252 & 268 & 284 & 298 & 303 & 298 & 288 & 282 & 288 & 05 & 334 & 344 & 351 & 367 & 365 & 349 & 322 & 291 & 265 & 250 & 243 & 241 & 240 & 239 & 239 & \\
\hline & $\pi$ & 238 & 251 & 261 & 284 & 300 & 310 & 311 & 306 & 302 & 304 & 314 & 335 & 345 & 359 & \begin{tabular}{|l}
310 \\
\end{tabular} & 369 & 352 & 325 & 291 & 214 & 260 & 2 & 24 & 241 & 239 & 239 & \\
\hline & & 250 & 210 & 20 & 315 & 33 & 338 & 35 & & & & & & 34 & 35 & 361 & & & & & & & & & & & & \\
\hline & 239 & 249 & 267 & 28 & 302 & 314 & 319 & 3 & 3 & 32 & 3 & 3 & 3 & 33 & 34 & 355 & 3 & 331 & 31 & 30 & 30 & 30 & 31 & 3 & 3 & 3 & 30 & \\
\hline & & 265 & 290 & 312 & 321 & 33 & 341 & 3 & 364 & 367 & 365 & 3 & & 35 & 364 & \begin{tabular}{|ll}
3 \\
\end{tabular} & 56 & 354 & & & & & & & 352 & & 364 & \\
\hline & & 288 & 322 & 35 & 364 & 371 & 378 & 386 & & & & & & 39 & 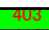 & 408 & 40 & 39 & 386 & 380 & 37 & 31 & 37 & 38 & 40 & 4 & 426 & \\
\hline 3. & 273 & 300 & 341 & 89 & 413 & 421 & 423 & 422 & 421 & 421 & 421 & 422 & 428 & 43 & 44 & \begin{tabular}{|l|l|}
46 \\
\end{tabular} & 44 & 430 & 422 & 41 & $\pi 7$ & 4 & $\pi \pi$ & 40 & 405 & 409 & 412 & \\
\hline & & & & & 437 & 450 & 450 & 462 & 466 & 469 & 470 & 469 & 460 & 46 & 46 & \begin{tabular}{|l|l}
458 \\
\end{tabular} & \begin{tabular}{|l|l}
48 \\
\end{tabular} & 43 & 43. & 4 & 43 & 4 & 434 & \begin{tabular}{|l|}
419 \\
\end{tabular} & 407 & 400 & 398 & \\
\hline 6.66 & 273 & 300 & 346 & 387 & 411 & 420 & 423 & 425 & 430 & 440 & 452 & 459 & 454 & 448 & 448 & \begin{tabular}{|l}
452 \\
\end{tabular} & 455 & 452 & 446 & 41 & 441 & 443 & 445 & & 442 & 439 & 438 & 4. \\
\hline
\end{tabular}

は，測線のP10〜P13より北側に60 m程度離れたと ころに設置してある固定式傾斜計の深さである 26 mが地すべり深さとして想定されるため，ジオフ オン間隔を $3 \mathrm{~m}$ や $4 \mathrm{~m}$ にするなど大きくして探査深 度を大きくすることも考えられるが，ここでは探 査の目的が表層の平均せん断波速度を求めること であり，その精度を向上させることを目的に $20 \mathrm{~m}$ とした。

図-13 に測線に沿うせん断波速度（Vs）の２次 元分布（（a）区間 1 と（b) 区間 2) を示す.これら の図の深さ方向の基準である地表面の起伏を考慮 した表現になっていない.P2 から $20 \mathrm{~m}$ 程度はな めらかに地表面の標高が約 $2.5 \mathrm{~m}$ 低くなる。表-3 に, この 2 次元 Vs 分布図（区間 1）の元となった 值を一覧にして示す. P2 側 $6 \mathrm{~m}$ までは信頼度が低 い. 区間 1 では，半無限弾性層が $26.6 \mathrm{~m}$ 以深で $470 \mathrm{~m} / \mathrm{s}$ が統一的に仮定されている. Vs が $450 \pm 10$ $\mathrm{m} / \mathrm{s}$ 以上になる最も浅い深さを見ると, 距離 22〜
$98 \mathrm{~m}$ で大半が 13.7〜 $16.7 \mathrm{~m}$ の層である. 他の距離 地点では現れない. $V s=400 \pm 10 \mathrm{~m} / \mathrm{s}$ となる最も浅 い深さを見ると，距離 $14 \sim 110 \mathrm{~m}$ で $10.8 \sim 13.6 \mathrm{~m}$ の層か 13.6〜 $16.7 \mathrm{~m}$ の層で現れる. 区間 2 では $\mathrm{Vs}=450 \pm 10 \mathrm{~m} / \mathrm{s}$ となる層はもちろん， $\mathrm{Vs}=400 \pm 10$ $\mathrm{m} / \mathrm{s}$ となる層も一部（P10-P11 付近）を除いて検出 されず，Vsの低い物質で構成されている.

いずれの区間でも，Vs=400 m/s程度の層が現れ た上位では浅くなるほどVsが低下する。最表層で のVsは，区間1の22～98 mを見ると，両端部でVs が300 m/sを下回るが区間中央では $350 \mathrm{~m} / \mathrm{s}$ を回ら ない。区間中央では道路の最も山側を通るように なるため結果的に堆積厚の小さい部分であるため かもしれない。区間2では240～300 m/s と低い.

そこで，最も浅いVs $=450 \pm 10 \mathrm{~m} / \mathrm{s}$ の深さを地震波 動の増幅を考える際の工学的基盤面と捉え, その 深さより浅い部分を表層とし, その深さまでの平 均せん断波速度Vs 䒚地すべり土塊のせん断波速度 
距離 $(\mathrm{m})$

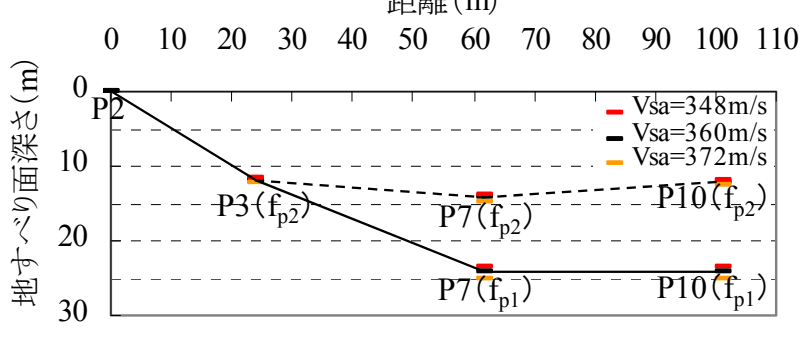

図-14Ｐ2 を距離の規準としたすべり面深さ分布

と仮定した.

$$
V s_{a}=\sum_{i=1}^{n} V s_{i} h_{i} / \sum_{i=1}^{n} h_{i}
$$

該当する距離22～98 m間の20の各距離断面での $\mathrm{Vs}_{\mathrm{a}}$ は, 最大值 $383 \mathrm{~m} / \mathrm{s}$, 最小值 $334 \mathrm{~m} / \mathrm{s}$, 平均值 359 $\mathrm{m} / \mathrm{s}$ ，標準偏差 $12 \mathrm{~m} / \mathrm{s}$ ，変動係数 $3 \%$ あ゙あ。したが って， $360 \mathrm{~m} / \mathrm{s}$ とれに $12 \mathrm{~m} / \mathrm{s}$ 考慮した場合を 検討して，誤差を検討することにする.

\section{（3）地すべり面深さの推定と検証}

(1)で読み取った卓越振動数 $f_{\mathrm{p}}$ と (2) で求めた平均 せん断波速度 $V s_{\mathrm{a}}$ を用いて, 次式により, 寸べり面 深さHを推定する.

$$
H=V s_{a} /\left(4 f_{p}\right)
$$

図-14にP2を距離の規準として，すべり面深さ 分布を示す. P2は地すべりブロック外の地点であ るP18に対して相対的に増幅することがないので $\mathrm{H}=0$ となる．その他の点はP3, P7, P10のいずれも 20 $\mathrm{m}$ 前後である.

この妥当性を検討するため, 寸でに明らかにな っている地すべり面深さを檜垣 ${ }^{11)}$ のすべり断面図 と比較する．檜垣は，図-15に示すような多数の 地すべり調査ボーリングの結果に基づいて，す心゙ り面の分布を縦断図, 横断図として整理している. 図-15のC測線が今回の我々の調査の測線に最も近 いため，これと比較する。図-16にC測線における 地す心゙りブロックの横断面図を示す．ここに，P2 を岩盤端部に相当するものとして, 他のP3, P7, P10の位置と地震観測の卓越振動数から推定した すべり深さを記入した。単一のピークを示して均 質表層を示唆していたP3では, 同じ物質で構成さ れ, 推定深さは地す心゙り面と一致する.P7では, 2つの推定深さは地すべり面とその上の岩屑物層 の上面に対して，それぞれ $5 \mathrm{~m}$ 程度下方に位置する。 P10では，2つの推定深さは地す心゙り面とその上部 の岩屑物の堆積層上面に対応している.

P3，P10の2点は，深い推定面が地すべり面と $5 \%$ 以内で一致した。P7では，35\%程度の誤差がある が，推定地質断面の測線と今回の探査測線との不 一致が影響しているかもしれない。これによれば,

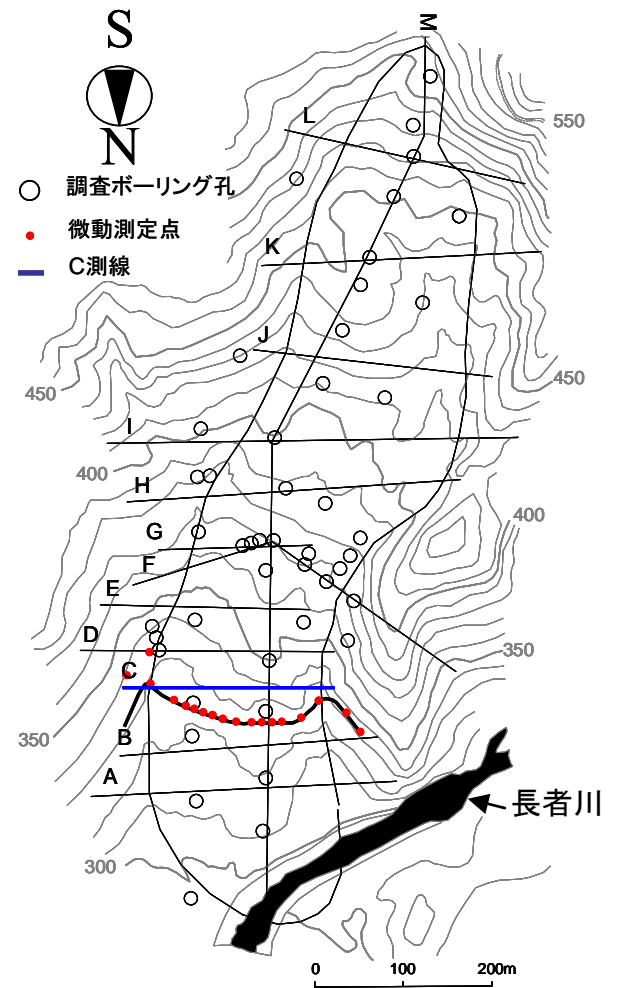

図-15 長者地すべり地における多数の地すべり 調査ボーリング地点と推定された地質断 面 (檜垣 ${ }^{11)}$ )

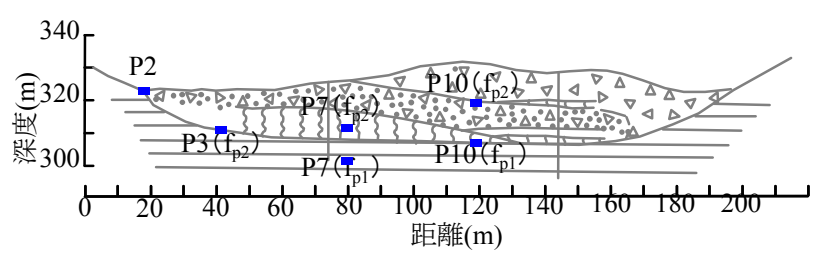

図-16 今回の調査測線に近い $\mathrm{C}$ 測線の地すべりブ ロック横断面図と提案する方法で評価され た地すべり面深さ

地すべり調査ボーリングの結果に基づいたす心゙り 面の位置の5３5\%（平均15\%）で推定できたこと になる。すなわち，68\%の確率で誤差 $30 \%$ 以内に 収まる過去の経験に基づく回帰式による推定より も高い精度で推定できると言える，期待した $14 \%$ の誤差程度となり, 概查の可能性は検証できたと 言える. また，この方法の原理をを地すべりブロ ックの横断・縦断に測線を設けて実施すれば， 3 次元形状の評価ができると考えられる.

\section{5. 結 論}

(1) 地すべり地の微動は振幅が低く, 電気ノイズ に埋もれてしまうことが多い。したがって，地す べり地の多くでは, 微動探查は有効に用いること が極めて困難である. 
(2) 2 日間の微小地震観測で3つの地震記録を得ら れた。低レベルの微動環境は微小地震観測に適し ている。防災科研や気象庁の地震観測情報の早期 公開は微小地震観測の成果把握を容易にさせる.

(3) 微小地震観測は，地すべり地における卓越振 動数の評価に有効である。また，周波数応答特性 や増幅特性の評価のためには主な周波数領域でSN 比が2以上が必要である。

（4）地すべりブロックの外側の安定した地山を基 準にしたときのブロック内側の移動土塊部分の水 平動スペクトル比（H/H比）は，地すべり地の地 震応答特性の評価に有効である。

（5）表面波探査により得られた地すべり土塊表層 の平均せん断波速度と微小地震観測により得られ た水平動スペクトル比 ( $\mathrm{H} / \mathrm{H}$ 比) の卓越振動数か ら，4分の1波長則に基づいて推定される地すべり 面深さは，すでに地すべり調査から精度良く得ら れている深さに対して 15\%程度の誤差で推定でき る可能性があることがわかった。詳細な地すべり 調査に先立つ概査としては，短期間で低コストな 調査法として成り立ちうる可能性を示した。

謝辞：本研究の一部は, 平成22年度砂防・地す心゙ り技術センター研究開発助成によりました。また, 高知県土木部には情報提供と観測への協力を戴き ました。長者地区の区長はじめ地元の方にはお世 話になりました。愛媛大学工学部地震工学研究室 の観測当時メンバーであった田村一樹, 古川 将 也，松村 裕樹，船越 徹也の各氏には観測で協力 を得ました。記して，謝意を表します。

\section{参考文献}

1)上野 将司：地すべりの形状と規模を規制する地形・
地質要因の検討, 地すべり, Vol.38, No.2, pp.105114, 2001.

2)＼cjkstart地すべりに関する地形地質用語委員会：地すべり 地形地質的認識と用語, 日本地すべり学会, $318 \mathrm{p}$, 2004.

3) 大竹 秀典, 森 伸一郎：地すべり地の振動特性, 第45 回地盤工学研究発表会発表講演集CD-ROM, pp.1877$1878,2010$.

4) 船越徹也, 森 伸一郎, 大竹秀典, 増田 信 : 地す心゙ り地における高密度微動測定と表面波探査による地 すべり土塊の推定, 平成22年度地盤工学会四国支部 技術研究発表会講演概要集, pp.73-74, 2010.

5) 森 伸一郎 : 微動測定による地盤 - 基礎構造物の健全 性評価一の応用, 第45回地盤工学研究発表会発表講 演集CD-ROM, pp.1861-1862, 2010.

6) 大竹 秀典, 森 伸一郎：地すべり地の微動における 信号とノイズ, 平成 22 年度地盤工学会四国支部技術 研究発表会講演概要集, pp.71-72, 2010.

7) 森 伸一郎, 古川将也: 谷池型ため池堰堤の微小地 震観測, 平成22年度, 農業農村工学会全国大会講演 要旨集, pp.336-337, 2010.

8) 森 伸一郎, 大竹 秀典, 船越 徹也 : 微小地震観測に よる地すべり地の地震応答特性, 平成 22 年度地盤工 学会四国支部技術研究発表会講演概要集, pp.75-76, 2010.

9) 仁淀村史編纂委員会編：仁淀村史，仁淀村(高知県), 仁淀村教育委員会事務局, 934p., 1969.

10) 防災科学技術研究所: 気象庁一元化処理 震源リス卜, http://www.hinet.bosai.go.jp/REGS/JMA/list/ (2010年9月28日アクセス)

11) 檜垣 大助：長者地すべり地における地すべり斜面の 変遷過程，地す心゙り，Vol.29, No.2, pp.12-19, 1992.

\section{ESTIMATION OF 3-D STRUCTURE AND EVALUATION OF SEISMIC RESPONSE PROPERTIES OF A LANDSLIDE BLOCK BY MICRO-EARTHQUAKE OBSERVATION}

\section{Shinichiro MORI and Hidenori OTAKE}

This paper demonstrates the efficiency of micro-earthquake observation for estimation of 3-D structure of a landslide block and evaluation of seismic response properties of a landslide site, showing an example of such an observation conducted at a national famous landslide area at Choja in Kochi Prefecture, Japan. First, we show that it is quite difficult to explore the landslide site in terms of underground S-wave velocity structure by conventional microtremor measurement because of extremely low level of ambient vibration. Next, we show that a three-day observation of micro-earthquake is effective for obtaining some recognizable micro-earthquake motions at the landslide site. Finally, we demonstrate that predominant frequencies specified according to the spectral amplification of the micro-earthquakes can be obtained at three observation points locating inside of the landslide block, and that depths of a sliding plane estimated by multiple reflection theory for one-dimensional soil column with both the predominant frequencies and the S-wave velocities obtained through multi-channel surface wave exploration agree with actual ones referred from a literature with $15 \%$ error. 